\title{
BJO
}

\section{Transthyretin levels in the vitreous correlate with change in visual acuity after vitrectomy}

E Van Aken, E A De Letter, M Veckeneer, et al.

Br J Ophthalmol 2009 93: 1539-1545 originally published online August 18, 2009

doi: 10.1136/bjo.2009.158048

Updated information and services can be found at:

http://bjo.bmj.com/content/93/11/1539.full.html

These include:

References This article cites 25 articles, 8 of which can be accessed free at: http://bjo.bmj.com/content/93/11/1539.full.html\#ref-list-1

Email alerting Receive free email alerts when new articles cite this article. Sign up in the service box at the top right corner of the online article.

Notes

To order reprints of this article go to:

http://bjo.bmj.com/cgi/reprintform

To subscribe to British Journal of Ophthalmology go to:

http://bjo.bmj.com/subscriptions 


\title{
Transthyretin levels in the vitreous correlate with change in visual acuity after vitrectomy
}

\author{
E Van Aken, ${ }^{1}$ E A De Letter, ${ }^{2}$ M Veckeneer, ${ }^{3}$ L Derycke, ${ }^{4}$ T van Enschot, ${ }^{5}$ I Geers, ${ }^{5}$ \\ $S$ Delanghe, ${ }^{5} \mathrm{~J}$ R Delanghe ${ }^{5}$
}

${ }^{1}$ Department of Ophthalmology, University Hospital Ghent, Ghent, Belgium; ${ }^{2}$ Department of Forensic Medicine, University Hospital Ghent, Ghent, Belgium;

${ }^{3}$ Rotterdam Eye Hospital, Rotterdam, The Netherlands:

${ }^{4}$ Upper Airway Research Laboratory, University Hospital Ghent, Ghent, Belgium;

${ }^{5}$ Department of Clinical Chemistry, University Hospital Ghent, Ghent, Belgium

Correspondence to: Dr E Van Aken, Department of Ophthalmology, University Hospital Ghent, De Pintelaan 185, B-9000 Ghent, Belgium; elisabeth.vanaken@ugent.be

Accepted 3 July 2009 Published Online First 18 August 2009

\section{ABSTRACT}

Background/aim: Little is known about biochemical markers related to change in visual acuity after vitrectomy. The potential use of transthyretin (TTR), a carrier of the retinol/retinol-binding protein, as a biochemical marker protein, was investigated.

Methods: TTR was measured using immunonephelometry in a group of patients $(n=77)$ in longstanding (>1 week) retinal detachment $(n=29)$, fresh $(<1$ week) retinal detachment $(n=17)$, macular holes $(n=20)$ or diabetic retinopathy $(n=11)$. Vitreous samples were taken at the start of every vitrectomy procedure. For reference values, cadaver specimens ( $n=73$ ) were used.

Results: Reference values for vitreous TTR (median $18 \mathrm{mg} / \mathrm{l}$; IQR 4 to $24 \mathrm{mg} / \mathrm{l}$ ) comprised $2.2 \%$ of reference values for vitreous protein levels (median $538 \mathrm{mg} / \mathrm{l}$; IOR 269 to $987 \mathrm{mg} / \mathrm{l})$. Vitreous TTR values of patients were comparable in all disorders. Vitreous TTR values were higher in phakic (median $22.5 \mathrm{mg} / \mathrm{l}$; IQR 10 to $27 \mathrm{mg} / \mathrm{l}$ ) than in pseudophakic patients (median $12 \mathrm{mg} / \mathrm{l}$; IQR 8 to $19 \mathrm{mg} / \mathrm{l} ; \mathrm{p}=0.06$ ). Postoperative change in visual acuity correlated well with vitreous TTR values found peroperatively $\left(r_{s}=0.408 ; p=0.012\right)$. Both change in visual acuity and lens status were the only variables which proved to explain the variance of TTR (multiple correlation coefficient: 0.494; phakic status: $t=2.767 ; p=0.0084$; and change in visual acuity $t=2.924: p=0.0056$ ).

Conclusion: Vitreous fluid concentrations of TTR can be regarded as a biochemical marker for retinal function.

Transthyretin (TTR) is a $55 \mathrm{kDa}$ homotetrameric protein with a dimer configuration that is synthesised in the liver, choroid plexus, visceral yolk sac and retinal pigment epithelium. Each monomer is a 127-residue polypeptide rich in beta sheet structure. Association of two monomers forms an extended beta sandwich. Further association of another identical set of monomers produces the homotetrameric structure. In serum, it functions as a carrier for thyroxin and retinol-binding protein (RBP). It has two thyroxin-binding sites per tetramer at the interface between the latter set of dimers, and two binding sites for RBP on the outer surface. As a carrier protein for thyroxin in serum, it acts in concert with thyroxin-binding globulin and albumin. Retinol is transported bound to RBP, which itself is bound to TTR. ${ }^{1}$ RBP has a higher affinity for TTR when it is bound to a retinol ester. ${ }^{2}$ The transport of protein-bound ligands across lipid-water interfaces, such as cell membrane surfaces, is thought to involve obligatory dissociation of protein-bound ligand into the free state before transmembrane transport. ${ }^{3}$ The retinol-RBP-TTR complex cannot pass freely through cell membranes. STRA6 is a multitransmembrane domain protein functioning as the high-affinity tissue receptor for plasma $\mathrm{RBP}$ and mediating cellular uptake of vitamin A from the vitamin ARBP complex. ${ }^{4}$ It has been suggested that formation of the complex between TTR and single, or multiple, RBP molecules prevents renal clearance of the retinol/RBP complex. ${ }^{5}$

In the eye, TTR is bound to retinol and RBP in various ocular tissues. In contrast to retinol, which is derived solely from the serum, TTR is synthesised locally. Plasma TTR does not cross the Bruch membrane into the retina. Ocular TTR is synthesised in the retinal pigment epithelium (RPE) and in the pigmented epithelium of the ciliary body, the corneal endothelium and the optic nerve fibre layer of the retina, and is transported to specific locations within the eye..$^{6-8}$ Although the physiological role of TTR in the eye is unknown, it is possible that it participates in retinol cycling.

TTR can be deposited as amyloid fibrils in senile systemic amyloidosis (SSA) and familial amyloid polyneuropathy (FAP). At least 20 TTR mutations are associated with amyloidosis. ${ }^{9}$ Vitreous amyloid fibrils are the result of local synthesis of mutated TTR. Nuclear cataract is associated with low protein intake and low serum levels of TTR. ${ }^{10}$ Immunohistochemical analysis of drusen in patients with age-related macular degeneration showed the presence of TTR. ${ }^{11}$ Comparison of aqueous humour between myopic and non-myopic patients showed a higher TTR level in the former. ${ }^{12}$

There exist no biochemical markers to differentiate between patients with excellent and poorer visual acuity after vitrectomy. Little is known about the TTR concentrations in normal and pathological human vitreous fluid. As there are no known reports of humans lacking TTR, the importance of TTR to vision has not been described. In view of the presumed key role of TTR in the vitamin A cycle, we wanted to explore the use of TTR in human vitreous fluid as a biochemical marker protein for retinal function.

\section{MATERIALS AND METHODS \\ Subjects}

Vitreous samples obtained from human cadavers $(\mathrm{n}=73)$, obtained through a vitreous tap $4 \mathrm{~mm}$ from the limbus in the temporal upper or lower quadrant, were used for establishing references values for TTR. In table 1 , the age, sex, postmortem interval and possible pre-existing diseases are provided. The median postmortem interval was 1.5 days (IOR 0.9 to 2.4 days). In addition, the cause, mechanism and manner of death of each 
Table 1 Overview of the postmortem reference group: control cases; $n=73$; age (years)

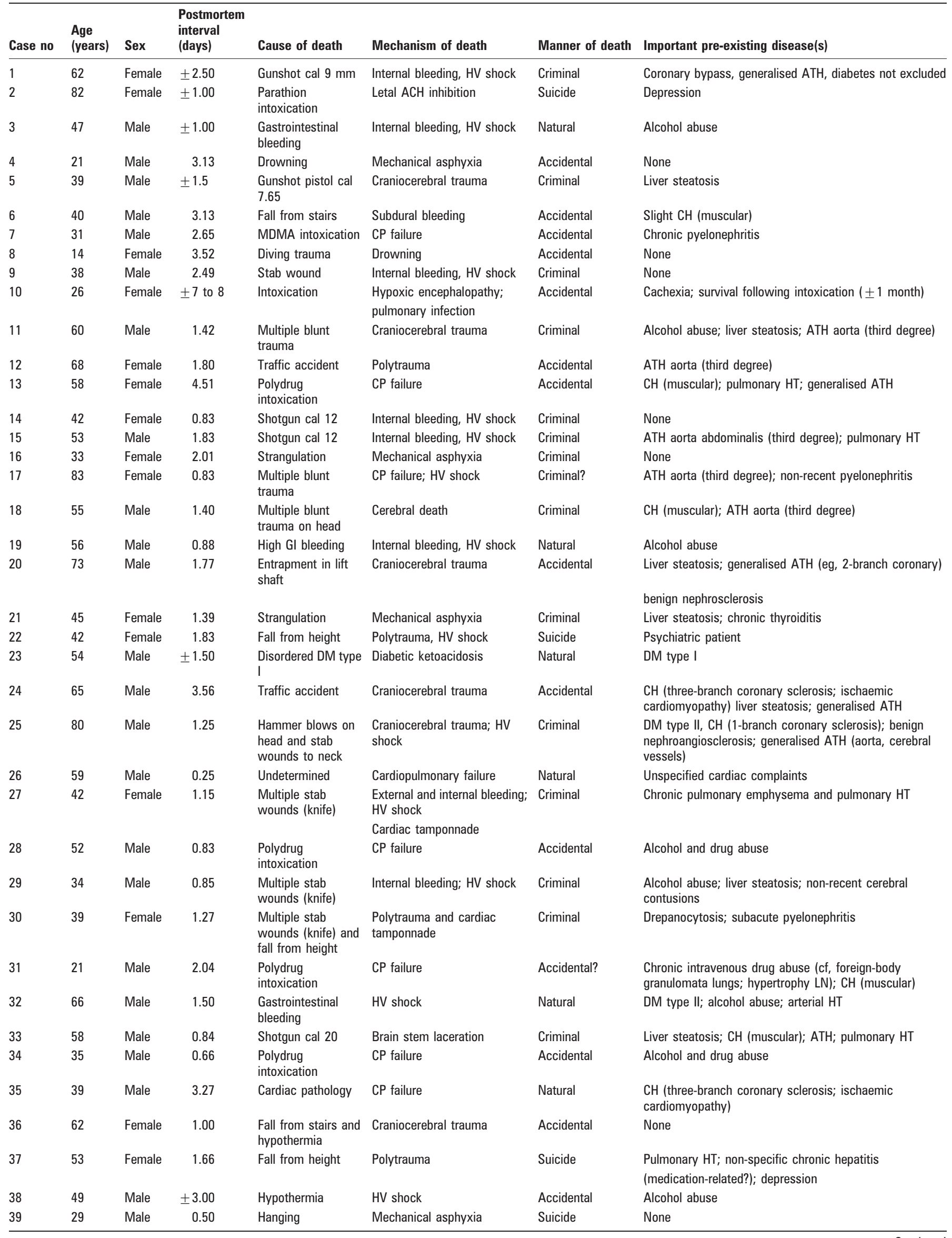


Table 1 Continued

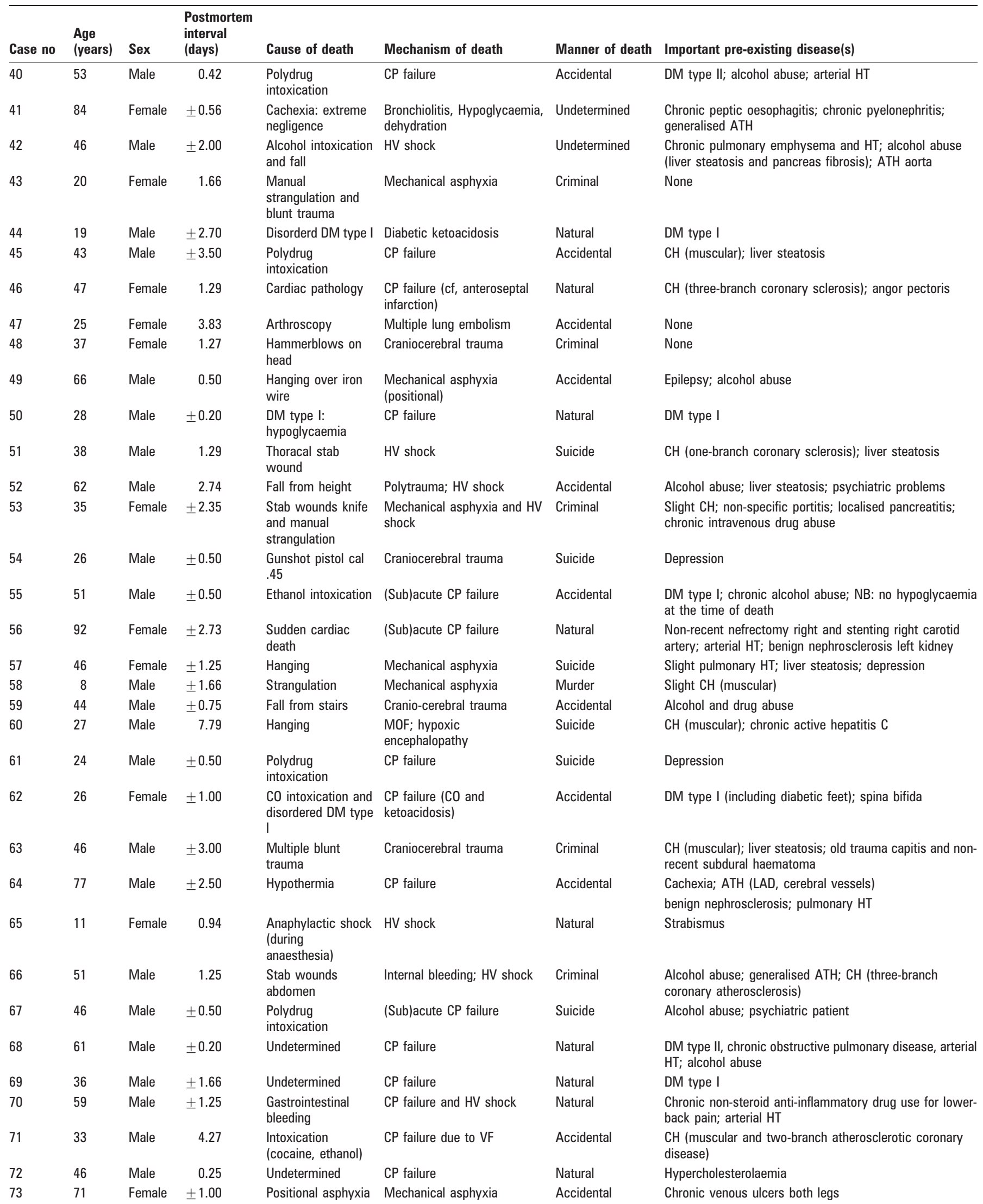

$\mathrm{ACH}$, acetylcholinesterase; $\mathrm{ATH}$, atherosclerosis; cal, calibre; DM, diabetes mellitus; $\mathrm{CH}$, cardiac hypertrophy; $\mathrm{CP}$, cardiopulmonary failure; HT, hypertension; HV, hypovolaemic shock. 
Table 2 Characteristics of patients

\begin{tabular}{lllll}
\hline & $\begin{array}{l}\text { Retinal detachment } \\
>\mathbf{1} \text { week }\end{array}$ & $\begin{array}{l}\text { Retinal detachment } \\
<\mathbf{1} \text { week }\end{array}$ & $\begin{array}{l}\text { Advanced proliferative } \\
\text { diabetic retinopathy }\end{array}$ & Macular hole stage 3 \\
\hline No & 29 & 17 & 11 & 20 \\
Age (range) & $71(61$ to 79$)$ & $57(51$ to 69$)$ & $56(50$ to 59$)$ & $71(61$ to 74$)$ \\
Phakic & $15(52 \%)$ & $6(35 \%)$ & $6(55 \%)$ & $14(70 \%)$ \\
Men & $13(45 \%)$ & $8(47 \%)$ & $7(64 \%)$ & $7(35 \%)$ \\
\hline
\end{tabular}

individual are specified. Furthermore, we analysed 77 freshly collected vitreous fluid samples submitted to our laboratory. Samples were collected by two vitreoretinal surgeons (MV in the Rotterdam Eye Hospital, The Netherlands, and EVA in Ghent University Hospital, Belgium). A vitreous tap of $0.5 \mathrm{ml}$ was performed at the start of every vitrectomy procedure via a syringe connected to the collecting cannula of the vitreous cutter. All samples were immediately stored at $4^{\circ} \mathrm{C}$. Informed consent was obtained from each patient. According to diagnosis, the patient could be divided in longstanding retinal detachment $(n=29)$, fresh retinal detachment $(n=17)$, macular holes $(n=20)$ or advanced proliferative diabetic retinopathy $(\mathrm{n}=11)$. As definitions, we used: "longstanding retinal detachment" for retinal detachments of patients with typical symptoms for a retinal detachment for at least 1 week before surgical intervention, "fresh retinal detachment" for retinal detachments of patients with typical symptoms for a retinal detachment for less than 1 week before surgical intervention, "macular hole" for stage $3(>400 \mu \mathrm{m})$ macular holes characterised by OCT existing more than 6 months and "advanced proliferative diabetic retinopathy" for patients with a fundus partially obscured by vitreous haemorrhage according to ETDRS standards. ${ }^{13}$ Pre- and postoperative visual acuity are measured using Snellen charts at $6 \mathrm{~m}$.

\section{Biochemical investigations}

TTR was measured immunonephelometrically on undiluted vitreous fluid samples using commercially available Behring antibodies on a Behring Nephelometer II analyser (Dade Behring) standardised against the widely accepted WHO/

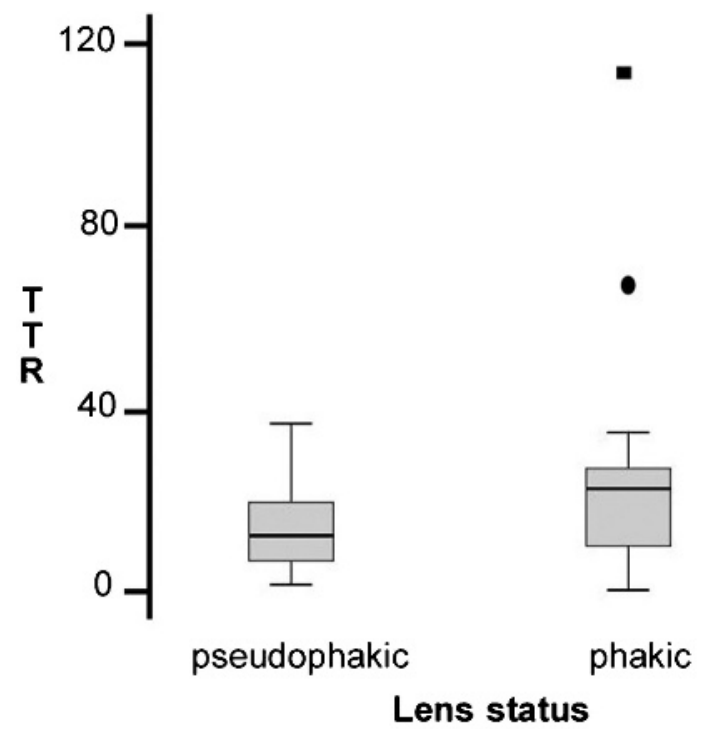

Figure 1 Box-whisker plots for transthyretin (TTR) values in vitreous samples of patients. Comparison between TTR values of pseudophakic and phakic patients. $p=0.064$; Mann-Whitney $U$ test.
College of American Pathologists Certified Reference Material 470. Total protein in vitreous fluid was measured by the Pyrogallol Red method $(n=129)$ with Standard Reference Material 917 a as a standard and commercially available reagents (Instruchemie, Delfzijl, The Netherlands) on a Modular P system (Roche). ${ }^{14}$ The 2.5 and 97.5 percentiles of the human cadaver specimens were used for calculating the reference interval. All samples were kept frozen at $-20^{\circ} \mathrm{C}$ until analysis. The between-run coefficient of variation was $5.86 \%$, and the detection limit was $3.35 \mathrm{mg} / \mathrm{l}$.

\section{Clinical investigations}

In the patient group, best-corrected visual acuity (Snellen) was evaluated before and 3-4 months after vitrectomy. The diagnosis of all preoperative conditions was made by funduscopy by a trained vitreoretinal surgeon. Additionally, optical coherence tomography (OCT) was performed for patients presenting with a macular hole. Patients who had undergone cataract surgery before were defined as "pseudophakic." Patients who had not yet undergone cataract surgery or had cataract surgery simultaneously with the vitrectomy were defined as "phakic." Characteristics of patients are found in table 2 .

\section{Statistics}

All $p$ values $<0.05$ were considered significant. Agreement between data was evaluated using the Spearman rank analysis. The lower limit of detection was calculated as the mean value -3 SD for a blank sample. Diagnostic accuracy was assessed by ROC analysis using commercially available statistical software

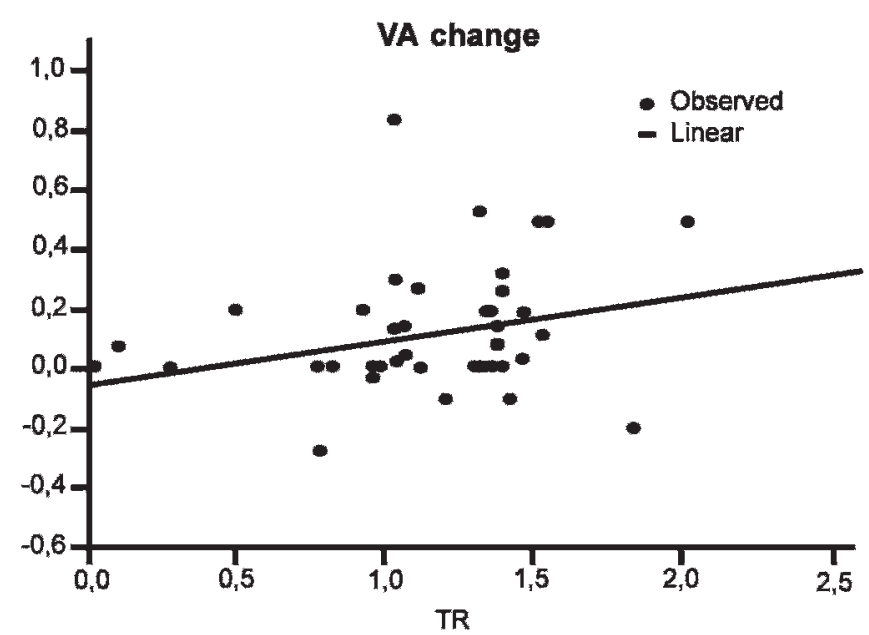

Figure 2 Correlation between vitreous transthyretin (TTR) concentration in patients and change in visual acuity (VA) postoperatively. Agreement was fair between the TTR concentration ( $x$ ) and the sight measurements $(y)$. The following regression equation was obtained: y (Snellen) $=0.0462+0.0042 \log X(\mathrm{mg} / \mathrm{l})$; Spearman rho $=$ $0.408 ; p=0.012 ; 95 \%$ confidence interval 0.106 to 0.641 . 
Table 3 Preoperative visual acuity (VA), postoperative VA and change in VA for all patients individually in Snellen $(6 \mathrm{~m})$

\begin{tabular}{|c|c|c|c|}
\hline & $\begin{array}{l}\text { VA } \\
\text { preoperatively }\end{array}$ & $\begin{array}{l}\text { VA } \\
\text { postoperatively }\end{array}$ & Change in VA \\
\hline Retinal detachment & 0.1 & 0.9 & 0.8 \\
\hline \multirow[t]{28}{*}{$>1$ week $(n=29)$} & 0.7 & 1.0 & 0.3 \\
\hline & 0.2 & 0.7 & 0.5 \\
\hline & 0.003 & 0.017 & 0.014 \\
\hline & 0.16 & 0.3 & 0.14 \\
\hline & 0.1 & 0.1 & 0 \\
\hline & 0.05 & 0.9 & 0.85 \\
\hline & 0.05 & 0.7 & 0.65 \\
\hline & 0.003 & 0.4 & 0.397 \\
\hline & 0.02 & 0.6 & 0.58 \\
\hline & 0.003 & 0.02 & 0.017 \\
\hline & 0.003 & 0.2 & 0.197 \\
\hline & 0.7 & 0.7 & 0 \\
\hline & 0.003 & 0.2 & 0.197 \\
\hline & 0.1 & 0.16 & 0.06 \\
\hline & 1.0 & 0.7 & -0.3 \\
\hline & 0.05 & 0.2 & 0.15 \\
\hline & 0.003 & 0.017 & 0.004 \\
\hline & 0.017 & 0.3 & 0.283 \\
\hline & 0.9 & 0.8 & -0.1 \\
\hline & 0.1 & 0.16 & 0.06 \\
\hline & 0.4 & 0.4 & 0 \\
\hline & 0.2 & 0.16 & -0.04 \\
\hline & 0.02 & 0.02 & 0 \\
\hline & 0.003 & 0.2 & 0.197 \\
\hline & 0.003 & 0.15 & 0.147 \\
\hline & 0.003 & 0.6 & 0.597 \\
\hline & 0.017 & 0.16 & 0.143 \\
\hline & 0.2 & 0.16 & -0.04 \\
\hline Mean (SD) & $0.2(0.28)$ & $0.4(0.3)$ & $0.2(0.3)$ \\
\hline Retinal detachment & 0.003 & 0.4 & 0.397 \\
\hline \multirow[t]{16}{*}{$<1$ week $(n=17)$} & 0.8 & 1 & 0.2 \\
\hline & 1.0 & 0.7 & -0.3 \\
\hline & 0.003 & 0.6 & 0.597 \\
\hline & 0.003 & 0.9 & 0.897 \\
\hline & 0.017 & 0.9 & 0.883 \\
\hline & 0.003 & 0.5 & 0.497 \\
\hline & 1.0 & 0.8 & -0.2 \\
\hline & 0.003 & 0.5 & 0.497 \\
\hline & 0.7 & 0.6 & -0.1 \\
\hline & 0.8 & 0.8 & 0 \\
\hline & 0.017 & 0.3 & 0.283 \\
\hline & 0.6 & 0.6 & 0 \\
\hline & 0.003 & 0.5 & 0.497 \\
\hline & 0.003 & 0.5 & 0.497 \\
\hline & 0.3 & 0.3 & 0 \\
\hline & 0.003 & 0.2 & 0.197 \\
\hline Mean (SD) & $0.3(0.4)$ & $0.6(0.2)$ & $0.3(0.3)$ \\
\hline Advanced proliferative & 0.1 & 0.3 & 0.2 \\
\hline \multirow[t]{10}{*}{ diabetic retinopathy $(n=11)$} & 0.017 & 0.2 & 0.183 \\
\hline & 0.2 & 0.3 & 0.1 \\
\hline & 0.4 & 0.4 & 0 \\
\hline & 0.4 & 0.4 & 0 \\
\hline & 0.003 & 0.003 & 0 \\
\hline & 0.6 & 0.6 & 0 \\
\hline & 0.2 & 0.3 & 0.1 \\
\hline & 0.3 & 0.3 & 0 \\
\hline & 0.6 & 0.5 & -0.1 \\
\hline & 0.16 & 0.4 & 0.24 \\
\hline Mean (SD) & $0.3(0.2)$ & $0.3(0.2)$ & $0.1(0.1)$ \\
\hline Macular hole stage 3 & 0.2 & 0.2 & 0 \\
\hline$(n=20)$ & 0.3 & 0.3 & 0 \\
\hline
\end{tabular}

Table 3 Continued

\begin{tabular}{llll}
\hline & $\begin{array}{l}\text { VA } \\
\text { preoperatively }\end{array}$ & $\begin{array}{l}\text { VA } \\
\text { postoperatively }\end{array}$ & Change in VA \\
\hline 0.16 & 0.2 & 0.04 \\
0.1 & 0.4 & 0.3 \\
0.3 & 0.3 & 0 \\
0.4 & 0.5 & 0.1 \\
0.15 & 0.4 & 0.25 \\
0.2 & 0.2 & 0 \\
0.3 & 0.3 & 0 \\
0.3 & 0.3 & 0 \\
0.3 & 0.3 & 0 \\
0.2 & 0.4 & 0.2 \\
& 0.02 & 0.02 & 0 \\
0.1 & 0.3 & 0.2 \\
0.4 & 0.7 & 0.3 \\
0.2 & 0.2 & 0 \\
Mean (SD) & 0.3 & 0.3 & 0 \\
& 0.2 & 0.3 & 0.1 \\
& 0.5 & 0.7 & 0.2 \\
& 0.6 & 0.6 & 0 \\
$0.3(0.1)$ & $0.3(0.2)$ & $0.1(0.1)$
\end{tabular}

Visual acuity of $0.017(1 / 60)$ equals fingers counting at $1 \mathrm{~m}$, visual acuity of $0.003(1 /$ 300 ) equals hand movement at $1 \mathrm{~m}$. The mean (SD) values for each patient group are given below. The Kruskal-Wallis one-way analysis of variance by ranks did not show any statistically significant difference between the patient groups $(p>0.05)$.

(MedCalc, SPSS, Chicago). The variance of TTR was studied using a stepwise backward elimination logistic regression model, starting with all covariates in the model followed by a stepwise removal of the term associated with the highest $p$ value.

\section{RESULTS}

\section{Reference values}

In the reference group ( $n=73$, median age: 46 years; IOR 35 to 58 years), the median total protein concentration was $538 \mathrm{mg} / \mathrm{l}$ (IOR 269 to $987 \mathrm{mg} / \mathrm{l}$ ). Considering the causes of death and the pre-existing pathologies, our control cases were a varied group and thus represent the normal population, including a few diabetics ( $n=10$; see table 1$)$. The distribution of total protein was skewed. The median TTR concentration was $18 \mathrm{mg} / \mathrm{l}$ (IOR 4 to $24 \mathrm{mg} / \mathrm{l}$ ) (table 2). The concentration of TTR was correlated with the total protein concentration of the vitreous fluid (correlation coefficient: $0.459 ; p<0.01)$. TTR concentrations were not significantly affected by the postmortem interval.

\section{Values in various pathological conditions}

The preoperative and postoperative visual acuities are list in table 3. The total protein levels in patients with fresh or longstanding retinal detachment and in patients with proliferative diabetic retinopathy were higher than total protein reference levels. Among the patient groups, the highest TTR values were recorded in the patients presenting with proliferative diabetic retinopathy and lowest in patients presenting with macular hole stage 3 (table 4). The median TTR values in any pathological condition did not differ statistically with reference TTR values. TTR values in patients who were phakic prior to the vitrectomy procedure (median $22.5 \mathrm{mg} / \mathrm{l}$ ) were higher than in pseudophakic patients (median $12 \mathrm{mg} / \mathrm{l}$ ) (fig 1). TTR/total protein ratios were calculated, as this ratio corrects for the vascular permeability changes. TTR/total protein ratios in any disease did not differ with reference TTR/total protein values. Preoperative vitreous TTR values correlated well with the visual outcome following treatment (fig 2). In a logistic regression model, both change in 
Table 4 Reference values and values for total protein and transthyretin (TTR) in vitreous fluid of the various patient groups

\begin{tabular}{|c|c|c|c|}
\hline & Total protein (mg/l) & TTR (mg/l) & TTR/total protein (\%) \\
\hline Retinal condition & Median (IOR) & Median (IOR) & Median (IQR) \\
\hline Reference & 538 (269 to 987$)$ & $18(4$ & $2.2(0.9$ to 3.9$)$ \\
\hline RRD $>1$ week old & $781^{*}(460$ to 1881$)$ & 19 (12 to 24$)$ & 1.6 (0.6 to 3.3$)$ \\
\hline $\mathrm{RRD}<1$ week old & $816^{*}$ (427 to 1527 ) & 14 (7 to 25$)$ & $1.8(1.7$ to 3.1$)$ \\
\hline Diabetes mellitus & $2326^{*}$ (1880 to 2818 ) & $20(10$ to 24$)$ & $1.3(1.2$ to 1.4$)$ \\
\hline Macular hole & 701 (241 to 1456 ) & 13 (9 to 25$)$ & 1.5 (1.1 to 3.2$)$ \\
\hline
\end{tabular}

The within- and between-run values for total protein and TTR are summarised. ${ }^{*} \mathrm{p}<0.05$ versus reference values; Mann-Whitney $U$ test.

IQR, interquartile ratio; RRD, rhegmatogenous retinal detachment.

visual acuity and lens status were the only variables which proved to explain the variance of TTR (multiple correlation coefficient: 0.494; phakic status: $\mathrm{t}=2.767 ; \mathrm{p}=0.0084$; and change in visual acuity $t=2.924: p=0.0056$ ).

\section{DISCUSSION}

This is the first report to the authors' knowledge about a biochemical marker related to change in visual acuity after vitrectomy and for measuring TTR in vitreous samples by immunonephelometry. In the present study, high concentrations of TTR (mean: $19 \mathrm{mg} / \mathrm{l}$ ) were found in vitreous fluid of cadaver eyes. The observed values are comparable with those observed in cerebrospinal fluid (mean: $17 \mathrm{mg} / \mathrm{l}$ ). The median serum TTR levels are $300 \mathrm{mg} / \mathrm{l}$ (IOR 250 to $350 \mathrm{mg} / \mathrm{l}$ ). The total protein levels in vitreous fluid are $538 \mathrm{mg} / \mathrm{l}$ and are comparable with total protein levels in serum and in CSF (150 to $500 \mathrm{mg} / \mathrm{l})$. Total protein levels in serum are much higher $\left(64 \times 10^{3}\right.$ to $\left.83 \times 10^{3} \mathrm{mg} / \mathrm{l}\right)$. The reference $\mathrm{TTR} /$ total protein ratios in the vitreous $(2.2 \%)$ greatly exceed the TTR/total protein levels in serum $(0.4 \%$ to $0.5 \%)$. The reference TTR values correlated with total protein levels in the vitreous. The origin of vitreous proteins includes the tissues surrounding the vitreous, the hyalocytes of the vitreous or the surrounding vasculature. The much higher TTR/total protein ratios found in the vitreous as compared with serum values suggest that simple diffusion from the serum cannot be the source of vitreous TTR. We conclude that the physiological level of TTR found in the vitreous of cadaver eyes is derived from surrounding tissues as RPE cells.

We found a significant correlation between postoperative change in visual acuity and high TTR concentrations in the vitreous preoperatively. Ramakrishnan et al found low TTR levels in the vitreous of patients with diabetes. ${ }^{15}$ TTR levels in the former study, however, were not measured by immunonephelometry but calculated semiquantitatively by densitometry after electrophoresis. Our results show that TTR levels in the vitreous are related not to diagnosis but to RPE function. TTR expression is a marker of differentiation of RPE cells in vitro. ${ }^{8}$ We presume a higher metabolic state of RPE cells in patients with high TTR expression, and thus a better regeneration after a vitrectomy procedure.

The function of TTR in the vitreous remains to be elucidated. RPE of the eye and choroid plexus of the brain are developmental and functional homologues, sharing many of the characteristics of transporting epithelia: the cells are joined by tight apical membrane junctions, and they regulate the transport of fluids and serum proteins into their respective humours. The secretion of TTR by the choroid plexus of the brain provides the mechanism for the regulation of $\mathrm{T} 4$ (thyroxin) levels in the brain. TTR in the CSF is involved in the delivery of T4 to stem cells and progenitor cells within the brain, which require T4 for regulation of the cell cycle. ${ }^{16}{ }^{17}$ The abundance of TTR mRNA in RPE is, except for the choroid plexus in the brain, unmatched by any other tissue of the body. ${ }^{8}$ TTR protein is secreted predominantly in an apical direction by RPE cells in vitro. ${ }^{18}$ The fact that the retinol metabolism is altered in TTR-null mice suggests that TTR plays a major role in the retinol metabolism in the interphotoreceptor matrix (IPM). ${ }^{19}$ Interphotoreceptor retinoid-binding protein (IRBP), a non-selective scavenger and stabiliser of retinoids released from photoreceptors and pigment epithelial cells, is the most abundant soluble protein component of the IPM. IRBP plays a direct role in the release of all-trans retinol from the rods. ${ }^{20}$ Alltrans retinol generated in rod photoreceptors upon the bleaching of rhodopsin is known to move from the rods to the RPE, where it is enzymatically converted to 11 -cis retinal in the retinoid visual cycle. Experiments conducted on toad RPE-eyecups, mammalian RPE cells and isolated RPE membranes indicate that IRBP specifically promotes the release of 11-cis retinal from the RPE apical surface, a step necessary for the movement of 11cis retinal to the rods. ${ }^{21}$ IRBP thereby directly supports the regeneration of rhodopsin in the visual cycle. ${ }^{22}$ An emerging concept is that the central role of retinoid-binding proteins in the visual cycle is to achieve tight control of retinoid concentration while protecting the retinal cells from the toxicity of free retinoids. In analogy with the CSF where thyroxin concentrations are titrated by binding to TTR, a spatial gradient of free IRBP molecules and IRBP/retinoid complexes might as well be regulated by TTR in the IPM.

We found higher TTR concentrations in phakic patients than in pseudophakic patients. The vitreous proteome is found to be different in pseudophakic patients. ${ }^{23}$ Lens cortical fibre debris, for example, leaks into the vitreous during cataract extraction. Cataract surgery might thus account for the easier passage of TTR from the posterior chamber to the anterior chamber, resulting in a higher outflow via the trabecular meshwork.

The total protein levels in the vitreous of patients with diabetes were 4.3-fold higher than the reference total protein levels. Electrophoresis of vitreous fluid proteins in diabetics revealed a plasma-like protein pattern, suggesting that the increased protein concentration is due to a major diffusion from the pathological vessels. Increased vascular permeability and pathological neovascularisation are major aspects of diabetic retinopathy. Reduced integrity of adherens junctions and tight junctions of human diabetic retina have been reported. ${ }^{24} 25$ TTR values in the vitreous of patients with diabetes were fairly similar to reference TTR values, as can be deduced from the following example. A vitreous cavity with a $4 \mathrm{ml}$ content filled with blood corresponds to an influx of only $12 \mu \mathrm{g}$ TTR from the serum into the vitreous cavity $(3 \mathrm{mg} / \mathrm{l} \mathrm{TTR} \times 4 \mathrm{ml})$. The amount of TTR that has originated from the serum into the vitreous cavity cannot cause a significant rise in the TTR concentration already present in the vitreous.

In conclusion, vitreous TTR concentrations strongly exceed the values obtained in serum. Therefore, their concentrations in vitreous fluid reflect local production by the RPE. The present study suggests that TTR can be used as a biochemical marker for assessing retinal function.

\section{Competing interests: None.}

Ethics approval: Ethics approval was provided by the Ethics Committee of University Ghent Hospital, Belgium.

Patient consent: Obtained.

Provenance and peer review: Not commissioned; externally peer reviewed. 


\section{REFERENCES}

1. Monaco HL, Rizzi M, Coda A. Structure of a complex of two plasma proteins: transthyretin and retinol-binding protein. Science 1995;268:1039-41.

2. Noy N, Slosberg E, Scarlata S. Interactions of retinol with binding proteins: studies with retinolbinding protein and with transthyretin. Biochemistry 1992;31:1118-24.

3. Mendel CM. The free hormone hypothesis: a physiologically based mathematical model. Endocr Rev 1989;10:232-74.

4. Kawaguchi R, Yu J, Honda J, et al. A membrane receptor for retinol binding protein mediates cellular uptake of vitamin A. Science 2007;315:820-5.

5. Kanai M, Raz A, Goodman DS. Retinolbinding protein: the transport protein for vitamin A in human plasma. J Clin Invest 1968;47:2025-44.

6. Getz RK, Kennedy BG, Mangini NJ. Transthyretin localization in cultured and native human retinal pigment epithelium. Exp Eye Res 1999;68:629-36.

7. Dwork AJ, Cavallaro T, Martone RL, et al. Distribution of transthyretin in the rat eye. Invest Ophthalmol Vis Sci 1990;31:489-96.

8. Pfeffer BA, Becerra SP, Borst DE, et al. Expression of transthyretin and retinol binding protein mRNAs and secretion of transthyretin by cultured monkey retinal pigment epithelium. Mol Vis 2004;10:23-30.

9. Sandgren $\mathbf{0}$. Ocular amyloidosis, with special reference to the hereditary forms with vitreous involvement. Surv Ophthalmol 1995;40:173-96.

10. Delcourt C, Dupuy AM, Carriere I, et al. Pathologies Oculaires Liées à l'Age study group. Albumin and transthyretin as risk factors for cataract: the POLA study. Arch Ophthalmol 2005;123:225-32.

11. Mullins RF, Russell SR, Anderson DH, et al. Drusen associated with aging and agerelated macular degeneration contain proteins common to extracellular deposits associated with atherosclerosis, elastosis, amyloidosis, and dense deposit disease. FASEB J 2000;14:835-46.

12. Duan $\mathbf{X}$, Lu $\mathrm{Q}, \mathrm{Xue} \mathrm{P}$, et al. Proteomic analysis of aqueous humor from patients with myopia. Mol Vis 2008;14:370-7.
13. Davis MD, Fisher MR, Gangnon RE, et al. Risk factors for high-risk proliferative diabetic retinopathy and severe visual loss: Early Treatment Diabetic Retinopathy Study Report \#18. Invest Ophthalmol Vis Sci 1998;39:233-52.

14. Orsonneau JL, Douet P, Massoubre C, et al. An improved pyrogallol red-molybdate method for determining total urinary protein. Clin Chem 1989;35:2233-6.

15. Ramakrishnan S, Sulochana KN, Parikh S, et al. Transthyretin (prealbumin) in eye structures and variation of vitreous-transthyretin in diseases. Indian J Ophthalmol 1999;47:31-4.

16. Richardson SJ. Cell and molecular biology of transthyretin and thyroid hormones. Int Rev Cytol 2007;258:137-93.

17. Lemkine GF, Raj A, Alfama $G$, et al. Adult neural stem cell cycling in vivo requires thyroid hormone and its alpha receptor. FASEB J 2005;18:863-5.

18. Ong DE, Davis JT, O'Day WT, et al. Synthesis and secretion of retinol-binding protein and transthyretin by cultured retinal pigment epithelium. Biochemistry 1994;33:1835-42.

19. Palha JA, Nissanov J, Fernandes R, et al. Thyroid hormone distribution in the mouse brain: the role of transthyretin. Neuroscience 2002;113:837-47.

20. Otaishat NM, Wiggert B, Pepperberg DR. Interphotoreceptor retinoid-binding protein (IRBP) promotes the release of all-trans retinol from the isolated retina following rhodopsin bleaching illumination. Exp Eye Res 2005;81:455-63.

21. Edwards RB, Adler AJ. IRBP enhances removal of 11-cis-retinaldehyde from isolated RPE membranes. Exp Eye Res 2000;70:235-45.

22. Pepperberg DR, Okajima TL, Wiggert B, et al. Interphotoreceptor retinoid-binding protein (IRBP). Molecular biology and physiological role in the visual cycle of rhodopsin. Mol Neurobiol 1993; 7:61-85.

23. Neal RE, Bettelheim FA, Lin C, et al. Alterations in human vitreous humour following cataract extraction. Exp Eye Res 2005;80:337-47.

24. Davidson MK, Russ PK, Glick GG, et al. Reduced expression of the adherens junction protein cadherin-5 in a diabetic retina. Am J Ophthalmol 2000;129:267-9.

25. Peters S, Cree IA, Alexander R, et al. Angiopoietin modulation of vascular endothelial growth factor: Effects on retinal endothelial cell permeability. Cytokine 2007;40:144-50. 
medical therapy (by Norbert Pfeiffer, Mainz) to the different laser techniques and the numerous surgical options. Trabeculectomy might still be the gold standard, but it increasingly has its competitors: shunts may be relatively safe and effective even as primary surgery for primary glaucomas, as Keith Barton (London) points out, while for Robert Stegmann, "Schlemm's canal surgery will continue to play an increasing role in the management of glaucoma as it is the most physiologic way to approach it."

Glaucoma therapy will remain one of the most challenging tasks for the ophthalmologist - and at the same time promises new developments like those that have propelled glaucoma diagnostics forward, for the benefit of our patients, so impressively. The annual Basel meeting and the book series of which Glaucoma Therapy: State of the Art is the latest (it is not available in bookstores but is now on sale online at http://www. glaucoma-meeting.ch) help to keep the audience and the readers in touch with a dynamic field of ophthalmology.

Competing interests: None.

R D Gerste

14801 Soft Wind Drive, Galtherburg, MD 20878, USA; info@glaucoma-meeting.ch

\section{Diabetic retinopathy for the comprehensive ophthalmologist}

By Jonathan Walker. Published by Deluma Medical, Fort Wayne, 2009, pp 280, \$39.99. ISBN-13 978-0-9821472-0-7

Diabetic Retinopathy for the Comprehensive Ophthalmologist delivers exactly what it promises: an appropriately balanced, straightforward guide to the management of diabetic retinopathy geared toward the general ophthalmologist. This book is not your traditional didactic reference. Informal and light-hearted, even self-deprecating at times, the author's tone allows this book to be read like a novel rather than a medical textbook. He elegantly balances humour and information, using anecdotes and mnemonics to reinforce key points.

The author assumes his readership has basic understanding of the ophthalmological exam and ancillary tests, and foregoes a primer on this subject. A thorough discussion of the principles and use of lasers, however, is included and is a must-read for retina fellows or any ophthalmologist interested in adding laser procedures to their armamentarium. Residents as well as practising ophthalmologists will likely find useful the chapter on pain control for patients undergoing panvetinal photocoagulation. An additional pearl is a chapter on cataract surgery in patients with diabetes, covering specific details regarding preoperative evaluation, intraocular lens selection, anaesthesia and management of postoperative complications.

The chapters are concise and intuitively organised with images from ancient and historical ophthalmology texts adorning the title pages. A reader can easily open this book for $10 \mathrm{~min}$ and take away three or four clinical pearls. Colour photographs underscore key principles, particularly in the chapter entitled "You Should Not Do Magic You Do Not Understand: Complications of Laser Treatment." The images of complications and "near-complications" serve admirably as reminders of the potential dangers of ophthalmic lasers.

Large, straightforward figures are found throughout the text, including useful tables for the appropriate timing of follow-up and figures detailing key information from the landmark papers on diabetic retinopathy. Also interspersed in the chapters are "boxes" containing practical advice that cannot be found in many desk references. These include tips on counselling patients prior to procedures and preparing them for the inevitable pitfalls they are likely to encounter due to their diabetic eye disease. By adopting these techniques, ophthalmologists will better garner the trust and confidence of their patients and reduce time spent explaining during future visits.

Diabetic Retinopathy for The Comprehensive Ophthalmologist is available for purchase at Amazon.com for \$39.99. If you cannot afford the purchase price, the author has generously made the entire textbook available as a free download at http:// www.drcobook.com

Competing interests: None.

J M Goshe

Cleveland Clinic Main Campus, Mail Code i13, 9500 Euclid Avenue, Cleveland, OH 44195, USA; goshej@ccf.org

\section{CORRECTION}

doi:10.1136/bjo.2009.158048corr1

Van Aken E, De Letter EA, Veckeneer M, et al. Transthyretin levels in the vitreous correlate with change in visual acuity after vitrectomy (Br J Ophthalmol 2009;93:153945). Line 8 of the Discussion should read "Total protein levels in vitreous fluid are $538 \mathrm{mg} / \mathrm{l}$ and are comparable with total protein levels in CSF (150-500 mg/l); ie, "in serum and" should have been omitted. 